\title{
TOMÁS ANTÔNIO GONZAGA EM VERSO E PROSA: COMENTÁRIO DE CINCO PUBLICAÇÕES RECENTES
}

\author{
André Figueiredo Rodrigues \\ Pós-graduando Depto. de História - FFLCH/USP
}

Minas Gerais, segunda metade do século XVIII. Vila Rica era o centro cultural e receptor das principais idéias européias que circulavam pela América portuguesa. Na literatura que se produziu naquele instante, os poetas vão se identificar com a terra em que vivem, vão demonstrar sentimentos comuns e interesses recíprocos. A natureza é representada como uma civilização em nascimento, em germe. $\mathrm{O}$ autor de literatura pertence ao seu estilo de época e revela a alma do seu tempo.

No setecentos mineiro ocorrera a dualidade entre o progresso, o apreço à razão civilizatória (presente no ideal iluminista) e a utopia da natureza (nativismo). Nos textos que aí se produziram, a Ilustração e o primitivismo vão andar juntos, como pode ser percebido nas produções de Cláudio Manuel da Costa, Tomás Antônio Gonzaga e Alvarenga Peixoto. Os poetas árcades mais conhecidos e estudados de nossa literatura.

Na segunda metade do século XVIII, o clima de nativismo começa a mesclar-se a uma produção literária que repercutirá a vida da América portuguesa e os seus anseios. Declarações de fidelidade a Portugal e composições laudatórias povoaram, lado a lado, um sentimento político que apresenta convicções contestatórias e progressistas.

A vida simples, não necessariamente rústica, a existência singela, a presença de pastores e pastoras serão os temas e os personagem prediletos de nossos poetas. Vários são os autores que escrevem naquele momento, entre eles destacam-se geralmente os nascidos em Minas Gerais ou ali radicados, entre 1730 e 1750 , e cujas obras foram divulgadas, basicamente entre 1770 e 1800: Santa Rita Durão (1722 - 1784), Cláudio Manuel da Costa (1729 - 1789), José Basílio da Gama (1741 - 1795), Tomás Antônio Gonzaga (1744 - 1810), Inácio José de Alvarenga Peixoto (1749 - 1793) e Manuel Inácio da Silva Alvarenga (1749-1814).

Rita Durão, o mais velho, retirou-se do Brasil quando era criança. Basílio da Gama e Silva Alvarenga passaram quase todos os seus anos de adultos fora das Minas Gerais. O restante, Cláudio, Alvarenga e Gonzaga conviveram um período de tempo curto, de 1782 a 1789, em Vila Rica. As trajetórias e atividades políticas exercidas na capitania mineira, a produção e o círculo literário que formaram, são os elementos 
que os une. Os três estiveram envolvidos na conjuração mineira de 1789. Portanto, é esta particularidade que possibilitou sua inserção na obra organizada pelo professor Domício Proença Filho, A Poesia dos Inconfidentes.

Esta edição contém, além da aludida poesia - até o momento completa - dos inconfidentes, textos de crítica literária consagrados pela historiografia pertinente às obras dos três conjurados, como o do historiador João Ribeiro, escrito em outubro de 1901 acerca da vida e da obra de Cláudio, publicado na edição que organizou em 1903 para a editora Garnier, intitulada Obras Poéticas de Cláudio Manuel da Costa; escritos do professor e filólogo português Manuel Rodrigues Lapa utilizados como prefácios as partes referentes à Gonzaga e Alvarenga. Aliás, autor das belas Obras Completas de Tomás Antônio, publicado em 1942 pela Editora Nacional e Vida e Obra de Alvarenga Peixoto, publicada pelo MEC/INL em 1960, indispensáveis a qualquer estudo sobre a poesia dos poetas inconfidentes, cuja obra a ele devemos a sua correta e precisa divulgação. Livros bases para a presente edição, já que se reproduziram a poesia ali tornada pública; Manuel Bandeira com o seu artigo A Autoria de Cartas Chilenas. Prova de Estilo Favorável a Gonzaga, publicado inicialmente na Revista do Brasil em 1940, e que pôs fim a acalorados debates sobre o verdadeiro autor do poema satírico, que ora se atribuía a Cláudio, ora a Gonzaga.

Ao lado destes, temos escritos inéditos, como o estabelecido pela professora Melânia Silva de Aguiar (UFMG) sobre a trajetória poética de Cláudio; Eliana Scotti Muzzi sobre o poema épico Vila Rica, também deste; Lúcia Helena (UFF e UFRJ) sobre Gonzaga e o seu posicionamento entre a lira e a lei; Paulo Roberto Dias Pereira (UFF) sobre as Cartas Chilenas e os impasses do Iluminismo na colônia; Letícia Malard (UFMG) sobre as louvações de Alvarenga e o riquíssimo painel histórico elaborado por Luciano Figueiredo (UFF) a respeito da inconfidência mineira, o seu percurso na historiografia e o envolvimento e participação dos poetas no intento sedicioso.

Em apêndice, a obra apresenta ainda espaço a reprodução de excertos dos Autos de Devassa da Inconfidência Mineira, que contém as inquirições sofridas pelos poetas. Além de uma ampla bibliografia sobre a inconfidência e sobre os três envolvidos.

Entre todas as coletâneas, a parte dedicada a Cláudio Manuel da Costa destaca-se com louvores. Apesar de não conter e, por sinal, nem se dar conta por parte dos organizadores do livro, da omissão presente no volume $2^{\circ}$ dos Autos de Devassa, de um trecho do único interrogatório a que foi submetido, a 2 de julho de 1789, quarenta e oito horas antes de aparecer morto no cárcere improvisado na Casa dos Contos. Trecho, aliás, muito significativo para se compreender as ligações de Cláudio com o governador Visconde de Barbacena. O fragmento citado encontrase reproduzido nas páginas 11 e 12 do volume $10^{\circ}$ dos Autos (edição patrocinada pela Câmara dos Deputados - Brasília - e pela Imprensa Oficial de Minas Gerais, em 1983).

Dos três, Alvarenga Peixoto é o menos estudado e conhecido, daí ser o mais problemático e controverso. Os ensaios sobre ele são os mais superficiais do livro, assim como a edição de seus poemas, não apresentando qualquer dado significativo aos já apresentados pela historiografia. Devemos observar ainda a grande dificuldade de se determinar com exatidão o seu corpus textual.

A obra, pelo modo como estão organizadas as coletâneas, interessa sobremaneira mais aos pesquisadores que se dedicam aos estudos dos três inconfidentes do que ao vasto público que procura atingir. Para o pesquisador é uma preciosa oportunidade de entrar em contato "particular" com estes textos, o que se tornava problemático, na maioria das vezes, pela dificuldade de os encontrar disponíveis para pesquisa, devido a sua raridade bibliográfica. 
De todos os poetas citados até o momento, Tomás Antônio Gonzaga é o personagem mais singular. Tem sido bastante estudado pela historiografia sob três aspectos: o poeta, o inconfidente e o tratadista de $\mathrm{Di}$ reito. Aqui vamos nos referir apenas ao poeta, eixo central de nossa análise.

O poeta é a sua expressão de maior conhecimento. Há quem o considere o maior lírico da língua portuguesa de sua época e um dos maiores dela de todos os tempos. Todavia, a sua imagem mais popular é a do pré-romântico presente em Marília de Dirceu, poema dividido em três partes e publicado de 1792 a 1812. A primeira parte, impresso em Lisboa pela Tipografia Numesiana, apareceu em 1792, e é esta a presente em Marília de Dirceo, edição fac-similar editada pela Fundação Biblioteca Nacional em 1995.

Esses versos líricos nos mostram a paixão de um pastor pela pastora Marília, Maria Joaquina Dorotéia de Seixas, a bela jovem que o árcade Dirceu enamora-se. Na primeira parte, o amor é visto como uma realização feliz em perspectiva de se concretizar.

Esta obra é a utilizada e reproduzida em A Poesia dos Inconfidentes, acrescentando-se as partes subsequentes, a segunda e a terceira. A segunda parte apareceu em 1799, editada pela Oficina Numesiana. Em 1812 a Impressão Régia publicou a terceira.

Ao lado do lirismo percorre outras vertentes do poeta: o sarcástico e o épico. O primeiro com as $C a r$ tas Chilenas que vão retratar através de sátiras o governo de Luís da Cunha Meneses por sua superposição do arbítrio ao direito, indicando os excessos, as suntuosidades, os subornos, as corrupções e as violências cometidas em seu governo.

Afim de apresentar ao público as deliciosas e burlescas poesias, em 1995 veio a público a edição organizada por Joaci Pereira Furtado das Cartas Chilenas. Primeiro volume da coleção Retratos do Brasil, uma versão atualizada da extinta Brasiliana, editada pela Companhia Editora Nacional.
Esses poemas satíricos percorreram Vila Rica antes da conjuração mineira, em forma manuscrita e anônima. As cartas são escritas por Critilo (o próprio Gonzaga) e dirigidas a Doroteu (supostamente, Cláudio Manuel da Costa), criticando o governador da capitania do Chile, Fanfarrão Minésio - pseudônimo de Cunha Meneses, que governou a capitania das Minas Gerais de 10 de outubro de 1783 a 11 de julho de 1788. Sempre em choque com outras autoridades, como por exemplo o ouvidor Tomás Antônio, as treze cartas que compõem a edição mostram um governo marcado pela corrupção e crueldade, através da pintura objetiva de uma sociedade. Não se deve imaginar porém que as cartas sejam um ataque frontal ao regime português. Nelas, Gonzaga satiriza pessoas e não instituições. É dentro deste padrão e convenções retóricas do Arcadismo que o poeta vai demonstrar alguns acontecimentos e sinais da década de oitenta do setecentos.

Joaci Furtado elaborou uma pequena introdução que refaz o caminho do aparecimento do manuscrito apógrafo e rápidos comentários sobre a estrutura textual do poema, uma cronologia sobre os fatos significativos da trajetória jurídica, poética, conjurada e bibliográfica dos escritos e de Gonzaga. As notas, a meu ver, são o ponto máximo da edição, apresentando informações e discussões vocabulares novas, aumentando ainda mais a compreensão do texto.

Estudando a receptividade do poema gonzagueano desde as suas primeiras incursões no tema, inicialmente desenvolvido durante a sua graduação em História pela Universidade Federal de Ouro Preto e complementado e ampliado durante a pós-graduação em História Social pelo Departamento de História da Faculdade de Filosofia, Letras e Ciências Humanas da Universidade de São Paulo, Joaci Pereira Furtado apresentou em 1994 a dissertação de mestrado intitulada Uma República de Leitores. História e Memória na Recepção das 'Cartas Chilenas' (1845 - 1989). 
Dois anos após a sua defesa, o trabalho foi agraciado com o Prêmio Moinho Santista, na categoria Juventude. Em 1997 recebeu o merecimento que lhe faltava, a publicação em livro, pela Editora Hucitec. No primeiro semestre de 1998, mais uma distinção chegou, agora um dos ganhadores do Prêmio Jabuti, na categoria Ensaio e Biografia.

A obra citada procura desvendar a apropriação das idéias do poema satírico gonzagueano pela memória como uma obra oficial da inconfidência mineira, observando as interpretações que surgiram desde 1845 , ano da publicação da primeira edição do poema e 1989, ano da bicentenário da conjuração de Minas Gerais. Apresenta um estudo das tendências interpretativas que mais auxiliaram nas novas e instigantes explicações acerca das cartas.

O livro divide-se em seis capítulos. No primeiro cuida da retórica literária presente no texto e o percurso das cartas na historiografia. No segundo capítulo mostra a relação conflituosa entre as realizações do governador Cunha Meneses e as atribuições de Gonzaga no posto de ouvidor geral de Vila Rica. No fundo o que quer Tomás Antônio é apresentar reflexões sobre o bom exercício do poder. Através da sátira reivindica um governo mais virtuoso para o Estado patrimonialista português. No item seguinte, percebe-se a dificuldade em separar o poeta do personagem real. O quarto capítulo analisa as posturas interpretativas da literatura como um espelho da história da sedição mineira, demonstrando que, mesmo a partir dos estudos surgidos a partir da década de 1950 e que procuraram romper esta tradição, a de que as cartas não são um reflexo da consciência nacional, esta idéia permanece contínua e presente nas discussões que medeiam, tanto Gonzaga quanto a inconfidência mineira. Justamente, no capítulo quinto esta discussão vem à tona, mostrando todos os seus meandros. A última parte apresenta uma tentativa de conclusão.

A última de nossas incursões pela obra de Gonzaga leva-nos a publicação do épico inédito A Conceição, edição crítica organizada pelo professor Ronald Polito de Oliveira da Universidade Federal de Ouro Preto.

O poema narra o naufrágio do navio Marialva na costa de Moçambique, ocorrido em 2 de setembro de 1802, um dia após ter saído do porto. Esse acontecimento inspirou Gonzaga, possivelmente a partir do falatório que corria na costa moçambicana, a escrever o poema. Restaram-nos apenas fragmentos dos cantos que compunham a obra. Temos duas passagens do primeiro canto e o terceiro e quarto cantos integrais, desconhecendo-se a extensão total do poema.

A partir de quarenta e duas páginas de fragmentos que encontrou na Biblioteca Nacional do Rio de Janeiro, Polito preparou para a presente edição uma transcrição diplomática, fiel a ortografia da época, e uma crítica, nos moldes ortográficos atuais; além de apresentar indícios sobre a trajetória de Tomás Antônio em Moçambique. Um dado merece ser comentado: a reprodução do manuscrito redigido pelo próprio poeta, em fac-símile dos 795 versos existentes.

A publicação deste épico em A Poesia dos Inconfidentes demonstra os efeitos proporcionados pela edição de Ronald Polito do manuscrito autógrafo, como a ampliação das pesquisas que propiciarão aos estudiosos gonzagueanos talvez cotejar outros poemas, além de tornar possível o cruzamento entre os seus textos, demonstrando a sua grande versatilidade literária. A única crítica a ser elaborada a edição patrocinada pela Editora Nova Aguilar é a ausência de uma única nota que diga respeito à transcrição realizada por Ronald ao texto A Conceição, publicado um ano antes. Aliás, esse mesmo texto serviu de base para a futura publicação - a carioca - ao que tudo indica.

A publicação destas cinco obras recentes é muito bem-vinda para que o público em geral tenha contato com a rica produção da literatura "mineira" do século XVIII, tornando-se, assim também, obras de referência indispensáveis para os estudos literários e 
historiográficos que por ventura utilizem com fonte de pesquisa os nossos poetas árcades.

Em suma, Tomás Antônio Gonzaga em verso e prosa continua a ser um personagem de múltiplas faces, tanto literária quanto biográfica, haja vista a quantidade de estudos que vem se realizando nos últimos anos. A mais recente e importantíssima con-

\section{Bibliografia}

COSTA, Cláudio Manuel da; GONZAGA, Tomás Antônio; PEIXOTO, Alvarenga. A Poesia dos Inconfidentes. Poesia Completa. Organização de Domício Proença Filho. Rio de Janeiro: Nova Aguilar, 1996. 1264p. (Biblioteca Luso-Brasileira. Série Brasileira)

GONZAGA, Tomás Antônio. Cartas Chilenas. Organização e edição crítica de Joaci Pereira Furtado. São Paulo: Companhia das Letras, 1995. 253p. (Retratos do Brasil, 1). tribuição é a tese de doutoramento na área de literatura portuguesa de Adelto Rodrigues Gonçalves, Gonzaga, um Poeta do Iluminismo (Vida e Época), defendida em outubro de 1997, na Faculdade de Filosofia, Letras e Ciências Humanas da Universidade de São Paulo. Mas esta, é um outra história, para um outro momento...

Endereço do Autor: Rua Itape, 4 - Jd. Maria Dirce - Guarulhos - São Paulo - SP - Brasil - CEP 07173-400 - E-mail: andrefr@usp.br 